\title{
Pizza and Hamburger Consumption to Overweight among Adolescents in Jambi City
}

\section{Konsumsi Pizza dan Hamburger terhadap Kegemukan pada Remaja di Kota Jambi}

\author{
Ummi Kalsum*, Sahridayanti Nainggolan**, Nawi Ng***
}

\begin{abstract}
*Public Health Studies Program, Faculty of Public Health, Universitas Jambi, Jambi, Indonesia, **Jambi Health Office, Jambi, Indonesia, ***Department of Public Health and Clinical Medicine UMEA University, Sweden
\end{abstract}

\begin{abstract}
Junk food is unhealthy and poor in nutrient quality, and may result in weight gain, obesity, and coronary heart disease, if consumed regularly. The prevalence of overweight in adolescents is $5-10 \%$ higher in urban areas. Adolescents undergo lifestyle changes, including in food consumption behavior. This study aimed to determine relation between junk food consumption patterns and overweight in adolescents. This study was conducted based on a cross-sectional design. A total of 137 high school students in Jambi City were involved in this study. Patterns of junk food consumption were assessed using food frequency questionnaires that examined the eating habits of study subjects. The variables were sex, maternal education, parents's occupation, and family's socio-economic level. Analysis was conducted using the chi-square test and multiple logistic regression. Nutritional status was measured using body mass index-forage with WHO Antro software. The results of this study indicated a $23.4 \%$ prevalence of overweight in adolescents. After controlling for maternal education, father's occupation, instant noodle eating habits, and tea, coffee and cookies consumption, final model showed that consumption of pizza and hamburgers among adolescents was the dominant determinant for overweight $(\mathrm{OR}=3.55)$. Consumption of pizza and hamburger was related to overweight among adolescents in Jambi City.
\end{abstract}

Keywords: Adolescent, junk food, nutritional status, overweight

\begin{abstract}
Abstrak
Makanan cepat saji merupakan makanan yang tidak sehat dan buruk, yang dapat menyebabkan penambahan berat badan/obesitas, dan penyakit jantung koroner jika dikonsumsi secara teratur. Prevalensi kegemukan pada remaja meningkat 5-10\%, lebih tinggi di daerah perkotaan. Remaja menjalani perubahan gaya hidup, termasuk dalam perilaku konsumsi makanan. Penelitian ini bertujuan mengetahui hubungan pola makanan cepat saji dengan kegemukan pada remaja. Penelitian dilakukan berdasarkan desain potong lintang. Sebanyak 137 siswa sekolah menengah atas di Kota Jambi dilibatkan dalam penelitian ini. Pola konsumsi makanan cepat saji dikaji menggunakan kuesioner frekuensi makanan terhadap kebiasaan makan. Variabel meliputi jenis kelamin, pendidikan ibu, pekerjaan orang tua, dan tingkat sosial ekonomi keluarga. Analisis menggunakan kai kuadrat dan regresi logistik ganda. Status gizi diukur menggunakan indeks massa tubuh menurut usia dengan perangkat lunak WHO Antro. Hasil penelitian menunjukkan prevalensi kegemukan sebesar $23,4 \%$. Setelah dikontrol oleh pendidikan ibu, pekerjaan ayah, kebiasaan makan mie instan dan konsumsi teh, kopi, cappuccino, dan kue. Model terakhir menunjukkan bahwa konsumsi pizza dan hamburger pada remaja merupakan faktor dominan kegemukan $(\mathrm{OR}=3,55)$. Konsumsi pizza dan hamburger berhubungan dengan kegemukan pada remaja di Kota Jambi.

Kata kunci: Remaja, makanan cepat saji, status gizi, gemuk

How to Cite: Kalsum U, Nainggolan S, Ng N. Pizza and hamburger consumption to overweight among adolescents in Jambi City. Kesmas: National Public Health Journal. 2018; 13 (2): 53-59. (doi:10.21109/kesmas.v13i2. 1694)

Correspondence: Ummi Kalsum, Public Health Studies Program, Public Health Faculty, Universitas Jambi, Raya Jambi-Muara Bulian Street Km. 15 Mendalo Darat Jambi, Phone: +62741-582965, E-mail: kalzoem@gmail.com Received: August 29th 2017

Revised: March 26th 2018

Accepted: September $26^{\text {th }} 2018$
\end{abstract}




\section{Introduction}

Adolescence is a transition period from childhood to adulthood. The teenage phase is between 13 and 18 years old. Adolescents are vulnerable, particularly during the second phase of rapid growth called the adolescent "growth spurt", they need plenty of nutrients for their growth. ${ }^{1}$ Alongside the physical growth in adolescents, they also experience social and psychological growth. This growth exposes adolescents to a variety of lifestyles and behaviors, including food consumption influenced by environment, family and media campaigns. Such advertising may highlight new low-nutrient food products, foods that supposedly maintain a slim body outline, or Western foods such as pizza and hamburgers.

According to data from the 2007 National Basic Health Research, consumption of unhealthy and poor quality junk food in the population aged 10 years was at $65.2 \% .^{2}$ Long term consumption of junk food may result in conditions such as obesity. The prevalence of obesity in adolescents aged 13-15 years in Jambi Province was $6.0 \%$. In youths between 16 and 18 years old, prevalence of obesity rose from about $1.4 \%$ in 2010 to $7.3 \%$ in 2014. ${ }^{3,4}$ Several studies observed a relationship between the consumption of junk food and the nutritional status of adolescents, particularly the incidence of overweight. The increase in prevalence of overweight among adolescents, particularly in urban areas, has led to a double burden of nutritional problems in Jambi, and in Indonesia as a whole. Excess nutrients can result in obesity, which occurs in children, youths and adults. Junk food causes obesity because it creates an imbalance between the amount of energy obtained and the amount of energy consumed by the body's need for growth and development, activity and immunity. ${ }^{5}$ Common complications from being overweight or obese include non-communicable diseases such as heart disease, hypertension, and diabetes mellitus.

The aim of this study was to determine relation between the consumption of junk food such as pizza and hamburgers, and overweight in adolescents. Other risk factors were to be studied as well.

\section{Method}

This study utilized a cross-sectional design with primary data collected from grade 10 high school students in Jambi City, Jambi Province. Data were collected in October of 2015. The study population included all 679 students at the Jambi 5 State Senior High School in Jambi City. A total of 149 participants were randomly selected from 18 classes of grade 10 students that met the inclusion criteria, were aged $<18$ years, and willing to participate in the study. Grade 10 students were selected because they were on average younger than 18 years of age. All subjects in this study obtained permission from the school to participate in this study. Students with an underweight nutritional status (-3 SD to $<-2 \mathrm{SD}$ ) were excluded, as this study aimed to compare overweight and obese participants to those of a normal nutritional status. As a result, a total of 137 subjects participated and completed this study.

The sample size calculated by hypothesis tests for a population proportion (two-sided) was carried out by the sample size determination software, Lemeshow and Lwanga. ${ }^{6}$ It used $\alpha=5 \%$ and $\beta=20 \%$. The dependent variable was being overweight, which was measured using body mass index-for-age (BMI/A). Calculation of $\mathrm{BMI} / \mathrm{A}$ was performed using the WHO Anthro software. The criteria for BMI/A (5-18 years old) was based on the Indonesian Ministry of Health (2011). ${ }^{7}$ To evaluate nutritional status, subjects were grouped into normal (-2 to 1 standard deviation of the $Z$ curve), and overweight (overweight + obese) ( $\geq 1$ SD of the $Z$ curve). Underweight subjects ( -3 to $-2 \mathrm{SD}$ of the $\mathrm{Z}$ curve) were excluded and not analyzed.

The main independent variable was consumption patterns of junk food including pizza and hamburgers, instant noodles, popcorns, chips and French fries, cake and sugary foods, soft drinks, as well as tea, coffee, cappuccino, cookies, and cakes.

Data were collected using a food frequency questionnaire (FFQ) with structured questionnaires which used a Likert scale with outcomes such as "never", "rarely", "sometimes", "often" and "always" to assess junk food consumption habits. The five Likert scale outcomes were re-coded into two categories. Outcomes 1-3, i.e. "never to sometimes" were re-coded into a single outcome of "rarely" (1), and outcomes 4-6, i.e. "often and always" were re-coded into "often" (2).

Nutritional status was measured directly using a digital scale (weighing scale) to the nearest $0.1 \mathrm{~kg}$. Height was measured using a portable height instrument made of super aluminum, with a tool accuracy of $0.1 \mathrm{~cm}$. It was previously used for measurement by the 2013 National Basic Health Research study. Measurements were conducted by a team of four trained enumerators, and monitored by the researchers from this study team.

As the research questionnaire was designed to be selfadministered, all other variables were filled directly into the research questionnaire. Analysis, including univariate analysis, bivariate analysis using the chi-square test, and multiple logistic regression analysis at the 95\% confidence level was conducted using a statistical software. Modelling with consideration of screening candidates was entered into the model using $\mathrm{p}$ value 0.25 , with the confounding test using the formula ((crude-adjusted/adjusted $* 100 \%$ ) > $10 \%$ ).

As a total of ten variables were analyzed in this study, the variables with a $p$ value 0.25 were pizza and ham- 
Table 1. Prevalence of Overweight and Distribution of Sociodemographic Characteristics

\begin{tabular}{lll}
\hline Variable & Criteria & $\%$ \\
\hline Nutritional status & Overweight & 23.4 \\
& Normal & 76.6 \\
Sex & Female & 52.6 \\
Father's education* & Male & 47.4 \\
& High & 88.1 \\
Maternal education*** & Low & 11.9 \\
& High & 83.3 \\
Mother's occupational status & Low & 16.7 \\
\multirow{2}{*}{ Father's occupation } & Employed & 38.0 \\
\multirow{2}{*}{ Socioeconomic level } & Unemployed & 62.0 \\
& Steady & 45.3 \\
& Not & 54.7 \\
\hline
\end{tabular}

Notes:

$\mathrm{n}=137$ for all variable except $* \mathrm{n}=135$ and $* * \mathrm{n}=132$

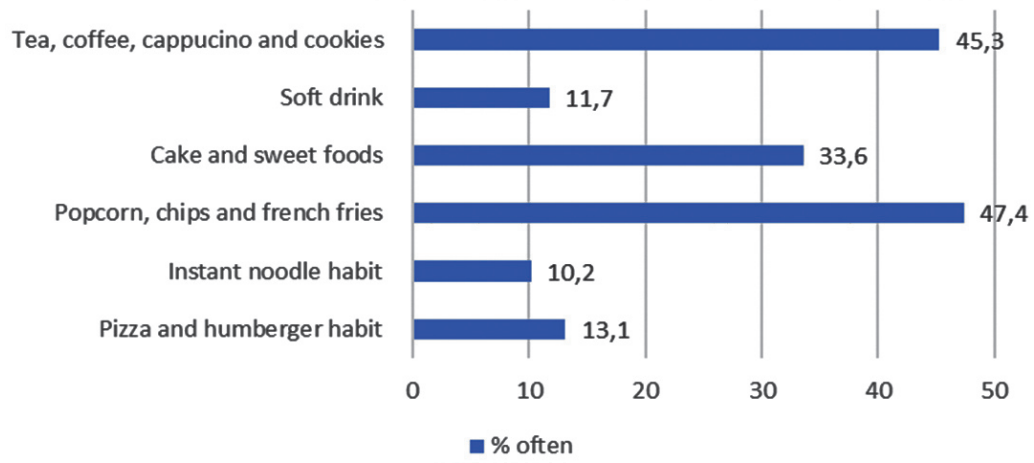

Figure 1. Junk Food Consumption Pattern in Adolescents, Jambi City

burger consumption, consumption of instant noodles, soft drinks, cakes and sweets, popcorn, chips and French fries, tea, coffee, cappuccino and cookies.

\section{Results}

Table 1 shows that $23.4 \%$ of the adolescents in this study were overweight. The study participants had a higher percentage of females, subjects with highly educated parents, unemployed mothers, fathers with unsteady occupation, and families in the middle to high socioeconomic range.

Figure 1 shows that "often" consumption of pizza and hamburgers, instant noodles and soft drinks in adolescents was $15 \%$. However, "often" consumption of popcorn, chips and fries and cake and sweets, and of tea, coffee, cappuccino and cookies was relatively high at $>30 \%$.

Table 2 shows that adolescents who consumed pizza and hamburgers "often" had a greater risk of being overweight than those who "rarely" consumed $(\mathrm{OR}=3.17$; $95 \% \mathrm{CI}=1.13-8.89$; $\mathrm{p}$ value $=0.035$ ). Adolescents with a father who held a steady job had a greater risk of being overweight than those with a father who did not hold a steady job $(\mathrm{OR}=2.5 ; 95 \% \mathrm{CI}=1.11-5.65 ; \mathrm{p}$ value $=$ 0.040). Consuming popcorn, chips and fries "often", having a highly educated mother, having an employed mother, and having a family in the middle to high socioeconomic level, all increased the risk of becoming overweight in adolescents of overweight in adolescents (OR $=1.14 ; 3.58 ; 1.37$ and 2.21, respectively). However, these increases were not proven to be statistically significant. Subjects with overweight and normal nutritional status were similarly distributed to "often" and "rarely" consuming instant noodles, soft drinks, tea, coffee, cappuccino and cookies, cake, and sweet foods. There was no statistical difference in overweight incidence across both sexes.

A final model based on multivariate logistic regression analysis is shown in Table 3. After controlling for consumption of instant noodles, tea, coffee, cappuccino and cookies, mother's education level, and father's occupation, the model revealed that adolescents who consumed hamburgers and pizza "often" had a greater risk of being overweight $(\mathrm{OR}=3.54)$ than those consumed them "rarely". Maternal education, father's occupation, consuming instant noodles, tea, coffee, cappuccino and 
Table 2. Bivariate Analysis for Factors Related to Overweight in Adolescents

\begin{tabular}{|c|c|c|c|c|c|c|c|c|}
\hline \multirow{3}{*}{ Variable } & \multirow{3}{*}{ Criteria } & \multicolumn{4}{|c|}{ Nutritional Status } & \multirow{3}{*}{ POR } & \multirow{3}{*}{$95 \% \mathrm{CI}$} & \multirow{3}{*}{ p Value } \\
\hline & & \multicolumn{2}{|c|}{ Overweight } & \multicolumn{2}{|c|}{ Normal } & & & \\
\hline & & $\mathbf{n}$ & $\%$ & n & $\%$ & & & \\
\hline \multirow[t]{2}{*}{ Pizza and Hamburger } & Often & 8 & 44.4 & 10 & 55.6 & 3.17 & $1.13-8.89$ & $0.04 *$ \\
\hline & Rarely & 24 & 79.8 & 95 & 20.2 & & & \\
\hline \multirow[t]{2}{*}{ Instant Noodle } & Often & 1 & 7.1 & 13 & 92.9 & 0.23 & $0.03-1.82$ & 0.19 \\
\hline & Rarely & 31 & 25.2 & 92 & 74.8 & & & \\
\hline \multirow[t]{2}{*}{ Pop Corn, Chips, French Fries } & Often & 16 & 24.6 & 49 & 75.4 & 1.14 & $0.52-2.52$ & 0.9 \\
\hline & Rarely & 16 & 22.2 & 56 & 77.8 & & & \\
\hline \multirow{2}{*}{ Soft Drink } & Often & 3 & 18.8 & 13 & 81.3 & 0.73 & $0.19-2.75$ & 0.76 \\
\hline & Rarely & 29 & 24 & 92 & 76 & & & \\
\hline \multirow{2}{*}{ Tea, Coffee, Cappuccino and Cookies } & Often & 10 & 16.1 & 52 & 83.9 & 0.46 & $0.20-1.07$ & 0.11 \\
\hline & Rarely & 22 & 29.3 & 53 & 70.7 & & & \\
\hline \multirow[t]{2}{*}{ Cake and Sweet Snacks } & Often & 9 & 19.6 & 37 & 80.4 & 0.72 & $0.30-1.71$ & 0.6 \\
\hline & Rarely & 23 & 25.3 & 68 & 74.7 & & & \\
\hline \multirow[t]{2}{*}{ Sex } & Female & 14 & 19.4 & 58 & 80.6 & 0.63 & $0.28-1.39$ & 0.35 \\
\hline & Male & 18 & 27.7 & 47 & 72.3 & & & \\
\hline \multirow[t]{2}{*}{ Maternal Education Level } & High & 29 & 26.4 & 81 & 73.6 & 3.58 & $0.79-16.27$ & 0.14 \\
\hline & Low & 2 & 9.1 & 20 & 90.9 & & & \\
\hline \multirow[t]{2}{*}{ Mother's Occupational Status } & Employed & 14 & 26.9 & 38 & 73.1 & 1.37 & $0.61-3.06$ & 0.57 \\
\hline & Unemployed & 18 & 21.2 & 67 & 78.8 & & & \\
\hline \multirow[t]{2}{*}{ Father's Job } & Steady & 20 & 32.3 & 42 & 67.7 & 2.5 & $1.11-5.65$ & $0.04 *$ \\
\hline & Not steady & 12 & 16 & 63 & 84 & & & \\
\hline \multirow[t]{2}{*}{ Socio-economic } & Middle to high & 31 & 24 & 98 & 76 & 2.21 & $0.26-18.70$ & 0.68 \\
\hline & Low & 1 & 12.5 & 7 & 87.5 & & & \\
\hline
\end{tabular}

Notes:

*p value $<0.05$

Table 3. The Final Model of Overweight and Junk Food Consumption Frequency, and Confounders

\begin{tabular}{|c|c|c|c|}
\hline Variable & B & Adjusted OR (95\% CI) & p Value \\
\hline Pizza and hamburger habit: often/rarely $(n=137)$ & 1.27 & $3.54(1.08-11.68)$ & 0.037 \\
\hline Instant noodle habit: often/rarely $(n=137)$ & -1.59 & $0.21(0.02-1.83)$ & 0.156 \\
\hline Tea, coffee, cappuccino and cookies: often/rarely $(n=137)$ & -0.81 & $0.45(0.18-4.77)$ & 0.079 \\
\hline Maternal education level: high/low $(n=132)$ & 0.78 & $2.17(0.44-10.73)$ & 0.341 \\
\hline Father's occupation: steady/not $(n=137)$ & 0.68 & $1.97(0.81-4.77)$ & 0.135 \\
\hline Constant & -1.96 & 0.14 & 0.011 \\
\hline
\end{tabular}

Overall percentage $=79.5 \%(\mathrm{p}$ value of omnibus test $=0.010)$

pastries were confounding factors for the incidence of overweight in adolescents in this model.

The most dominant predictor for becoming overweight in adolescents aged 14-17 years was consuming pizza and hamburgers. More highly educated adolescents had a $20 \%$ risk of being overweight, and those with employed fathers had a $10 \%$ risk of being overweight. This model was satisfactory because it was able to predict adolescent overweight incidence by $79.5 \%$.

\section{Discussion}

As a group, adolescents are susceptible to malnutrition because they are in a second phase of growth spurt, just before adulthood. Adolescents who live in urban areas are greatly influenced by their external environment including friends, family, and hedonistic lifestyle. ${ }^{8,9}$ The characteristics of urban adolescents are relatively differ- ent from rural adolescents. Middle to high socioeconomic class, highly educated parents, and working mothers tend to influence the lifestyle and food consumption patterns of adolescents. ${ }^{10,11}$

The growth of the fast food industry has been accelerated by aggressive advertisement of low-nutrient food products, particularly visible to adolescents in urban areas. This increases the consumption of junk food among adolescents. ${ }^{10,11}$

This study intended to prove the hypothesis that consuming junk food "often" may increase the risk of adolescents becoming overweight. After controlling for maternal academic level, father's occupation, consuming instant noodles "often", and consuming tea, coffee, cappuccino and cookies, this study found that consuming pizza and hamburgers "often" was the dominant predictor for being overweight in adolescents. This is similar to 
results obtained from previous studies that found that obesity is influenced by the energy intake from junk food consumption $(\mathrm{OR}=1.58,95 \% \mathrm{CI}=1.08-2.32$ and $\mathrm{p}$ value $=0.01) .{ }^{10}$ Also in line with a study by Badjebar, students who consume junk food 'often' at least three times a week are 3.28 times more likely to be overweight than those who consume "rarely". This result was statistically significant. ${ }^{12}$ Damapolii et al showed that the occurrence of obesity was related to consumption of junk food. ${ }^{13} \mathrm{~A}$ strong association between the consumption of junk food and obesity was reported among adults in Michigan. Regular consumers of junk food were $60 \%$ to $80 \%$ more likely to be obese higher compared to those who consumed junk food less than once per week. ${ }^{14}$

However, this study finding was not consistent with results from the study in Yogyakarta, which found that the frequency of junk food consumption was not related to a child's nutritional status ( $\mathrm{p}>0.05) .{ }^{15}$ This difference is likely because the participants of the Yogyakarta study were elementary school children. The percentage of children who consumed junk food "often" in the Yogyakarta study was only $4.6 \%, 63 \%$ of the children consumed junk food at a "rare" frequency, and $32 \%$ never consumed junk food. Due to limited financial power, primary school children only bought or consumed junk food when facilitated by their parents. In a study by Grace and Indasari, ${ }^{16}$ excessive consumption of carbohydrates was associated with the incidence of obesity among high school students in Makassar ( $p$ value $=0.000$ ). However, frequency of junk food consumption was not related to obesity $(\mathrm{p}$ value $=0.686)$.

Adolescents in Indonesia are currently experiencing a lifestyle change. Today, Western junk food such as fried chicken, French fries, pizza, doughnuts, burgers, hot dogs and ice cream are preferred and desirable. Most junk food are nutritionally imbalanced with high calories, fat, sugar and sodium levels but low fiber, vitamin A, ascorbic acid, calcium and folate levels. Excessive consumption of such foods causes nutritional problems such as overweight and obesity. ${ }^{12}$

Burgers and pizzas are main components of the Western diet. Consumption of pizza and burgers in Indonesia began in the 1990's. Furthermore, the proliferation of fast food restaurants with menus including hamburgers and pizza has increased their popularity. Previously, pizza and hamburgers could only be enjoyed by the upper and middle class. However, due to socioeconomic progress, hamburgers and pizza are now more accessible and affordable (IDR 2,500-4,000), making them available to people in the middle and lower socioeconomic class. ${ }^{17}$

The hamburgers currently in the market are composed of 13\% cholesterol and carbohydrate, and 30\% fat and saturated fat. Compared to hamburgers, pizzas are quite nutritious, containing minerals, fiber, vitamins B1, B2, B3 and vitamin A. Eating two slices of pizza, will provide most major nutrients and up to 410 calories (20.5\% of the daily requirement); 126 calories of fat $(6.3 \%) ; 14$ grams total fat $(22 \%) ; 40 \mathrm{mg}$ cholesterol (13\%); and $1,178 \mathrm{mg}$ sodium (49\%). Consumption of pizza satisfies of a person's daily saturated fat requirements. However, saturated fats are linked to degenerative diseases e.g. heart disease. ${ }^{15}$

Previously, pizza was considered a healthy food because it was made with an ideal composition of flour, tomato, olive oil and mozzarella. However, because of the use of many commercially affordable processed products, pizza now contains too much fat, calories, sodium but is low in nutrition value. As a result, pizza is now categorized as junk food. ${ }^{15}$ This study showed that consuming pizza and hamburgers "often" was the dominant predictor for being overweight among adolescents in Jambi City.

In a study by Bowman, ${ }^{18}$ consuming large portions of foods, foods with high energy density, high fat content, high sugar and salt content, high glycemic index and low in fiber increased energy intake, and spurred a positive energy balance. This increased the risk of obesity. Children and adolescents who consume junk food have higher levels of total calories, total fat, saturated fat, total carbohydrates, sugar but lower levels of fiber than children and adolescents who do not consume junk food. ${ }^{18}$

The high energy density of fat promotes increased energy intake. Total fat is associated with accumulation of adipose tissue. Junk food contains high levels of starch and sugar, and has a high glycemic index value. Therefore, it can stimulate energy intake. ${ }^{18}$ When the body consumes a high glycemic index food, the source of energy used comes from glycogen (carbohydrate deposits), so that fat is accumulated unused. If this is repeated continuously, fat deposits will accumulate, become abnormal and cause overweight and obesity. ${ }^{19}$

Some Western junk foods also contain several nutrients such as fat, protein, vitamins and minerals in moderate to high quantities. However, most of Western junk foods have a bad impact because they contain large amounts of saturated fat, cholesterol, sodium and highcalorie salt e.g. hamburgers and pizza. About $40-60 \%$ of calories from Western junk food are fat. Ingredients such as cheese, mayonnaise, creams and the use of deep-frying methods increase the high fat content of these foods. ${ }^{18}$

Some types of foods contain higher than the recommended levels of sodium. Likewise, soft drinks have high sugar content, which contributes significantly to the number of calories consumed. Furthermore, the fiber content in junk food is way below the recommended levels. ${ }^{20}$ Junk food consumption begins to show a significant association with the incidence of obesity when it ex- 
ceeds one-third of total daily caloric intake. ${ }^{17}$

Junk food also affects the body's energy level. Junk food does not contain many of the nutrients that the body needs. The high level of sugar in junk food causes metabolic dysfunction. The pancreas secretes high amounts of insulin to prevent dangerous spikes in blood sugar levels because fast food and junk food do not contain enough amounts of protein and carbohydrates. Junk food contributes to poor performance and obesity. The more overweight an individual is, the higher the risk for chronic diseases such as diabetes, heart disease, and arthritis. ${ }^{20}$

A study by Mahdiah et al, ${ }^{20}$ showed that urban junior high school adolescents consumed more types of junk food, because fast food restaurants or counters in the city provided more varied menus than restaurants in rural areas. ${ }^{21}$ There is an increase in the number of overweight children and adolescents because children and adolescents consume Western junk food, which contains more energy and less fiber. ${ }^{13,22}$

There are several limitations in this study e.g. the frequency of consuming junk food was only evaluated qualitatively (using a Likert scale with criteria ranging from "never" to "always consume"). However, the criteria range was defined to the respondents before they filled the questionnaire. Further studies need to utilize better study methods, add variables in accordance with the substance of the study, increase the number of samples, and utilize better measurements to identify junk food consumption patterns among adolescents or other vulnerable groups.

\section{Conclusion}

This study concludes that after controlling for maternal education levels, paternal occupation, consumption instant noodles, tea and coffee, cappuccino so cookies, consuming pizza and hamburgers "often" is the dominant risk factor for being overweight among adolescents. Consuming junk food "often" is mostly influenced by the high level of maternal education. Working mothers, on average, have less time to prepare and serve healthy foods at home. This influences the consumption pattern of the adolescent towards the consumption of low-nutrient junk food.

It is necessary to provide education, communication and information to parents, especially mothers on selecting healthy foods and providing a balanced diet for adolescents, to decrease the incidence of overweight or obesity. Creative and innovative communication and education programs on food consumption patterns and the dangers of junk food on adolescent health should be encouraged and implemented.

\section{References}

1. Adriani M, Wirjatmadi B. The role of nutrition in the life cycle. Jakarta:
Group of Kencana Prenada Media. 2012

2. Kementerian Kesehatan Republik Indonesia. Riset kesehatan dasar 2007: laporan nasional 2007. Jakarta: Kementerian Kesehatan Republik Indonesia; 2008. p.205.

3. Kementerian Kesehatan Republik Indonesia. Riset kesehatan dasar 2010. Jakarta: Kementerian Kesehatan Republik Indonesia; 2010. p.60.

4. Kementerian Kesehatan Republik Indonesia. Riset kesehatan dasar 2013. Jakarta: Kementerian Kesehatan Republik Indonesia; 2013. p.222.

5. Sartika RAD. Faktor risiko obesitas pada anak 5-15 tahun di Indonesia. Makara Kesehatan. 2011; 15(1): 37-43.

6. Lemeshow, S, Hosmer DW, Klar J, Lwanga SK, World Health Organization. Adequacy of sample size in health studies. England: John Wiley and Sons; 1997.

7. Menteri Kesehatan Republik Indonesia. Keputusan menteri kesehatan Republik Indonesia nomor: 1995/Menkes/SK/XII/2010 tentang standar antropometri penilaian status gizi anak. Jakarta: Kementerian Kesehatan Republik Indonesia; 2010. p.36-40.

8. Cuzzocrea F, Larcan R, Lanzarone C. Gender differences, personality and eating behaviors in non-clinical adolescent. Eating and Weight Disorders. 2013; 17(4): e282.

9. Newmark-Sztainer D, Story M, Perry CL, Cassey MA. Factors influencing food choices of adolescent. Journal of the American Dietetic Association. 1999; 99(8): 929-937.

10. Nurwanti E, Hadi H, Julia M. Paparan iklan junk food dan pola konsumsi junk food sebagai faktor risiko terjadinya obesitas pada anak sekolah dasar kota dan desa di Daerah Istimewa Yogyakarta. Journal of Nutrition and Dietetics Indonesia (Indonesian Journal of Nutrition and Dietetics). 2016;1(2): 59-70.

11. Story M, Neumark-Sztainer D, French S. Individual and environmental influences on adolescent eating behaviors. Journal of the American Dietetic Association. 2002; 102(3): S40-S51.

12. Badjeber F, Kapantouw, NH, Punuh M. Konsumsi fast food sebagai faktor risiko terjadinya gizi lebih pada siswa SD Negeri II Manado. Kesmas: Jurnal Kesehatan Masyarakat Universitas Sam Ratulangi. 2012; (1): 1114.

13. Damapolii W, Mayulu N, Masi G. Hubungan konsumsi fastfood dengan kejadian obesitas pada anak SD di Kota Manado. Jurnal Keperawatan. 2013; 1(1): 1-7.

14. Anderson B, Lyon Callo S, Fussman C, Imes G, Raffety AP. Fast food consumption and obesity among Michigan adults. Preventing Chronic Diseases. 2011; 8(4): A71.

15. Kushardianti T, Sudargo T. R. Hubungan antara keputusan memilih restoran fast food dan frekuensi konsumsi fast food terhadap status gizi anak sekolah dasar [Skripsi]. Yogyakarta: Universitas Gadjah Mada; 2014.

16. Anugrah AA, Indriasari R, Yustini. Hubungan konsumsi fast food dengan kejadian overweight pada remaja di SMA Katolik Cendrawasih Makassar [Skripsi]. Makassar: Universitas Hasanuddin; 2014.

17. Banowati L, Nugraheni N, Puhita N. Risiko konsumsi western fast food dan kebiasaan tidak makan pagi terhadap obesitas remaja studi di SMAN 1 Cirebon. Media Medika Indonesiana. 2011;45(2): 118-24.

18. Bowman SA, Gortmaker SL, Ebbeling CB, Pereira MA, Ludwig DS. Effects of fast-food consumption on energy intake and diet quality 
among children in a national household survey. Pediatrics. 2004; 113(1): 112-8.

19. Apriadji WH. Healthy fast food, fast food healthy dishes, favorites of children and the whole family. Jakarta: Gramedia Pustaka Utama; 2007.

20. Mahdiah. Prevalensi obesitas dan hubungan konsumsi fast food dengan kejadian obesitas pada remaja SLTP kota dan desa di Daerah Istimewa Yogyakarta. Jurnal Gizi Klinik Indonesia. 2004; 1(2): 69-77.

21. Putra RO. Junk food berkontribusi terhadap kinerja buruk dan obesitas.
2013. Available from: http://sumsel.tribunnews.com/m/index.php/ 2013/02/27/junk-foodberkontribusi-terhadap-kinerja-buruk-dan-obesitas.

22. Daradkeh G, Muhannadi A, Chandra P, Al Hajr M. Fast food vs healthy food intake and overweight/obesity prevalence among adolescents in The State of Qatar. Journal of Obesity Treatment and Weight Management. 2018; 1(1): 1-4. 